\title{
PERFORMANCE OF PHOTOVOLTAIC AND GROUND SOURCE HEAT PUMP SYSTEM FOR DAYTIME COOLING OF MUSHROOM GREENHOUSE DURING SUMMER: PRELIMINARY ANALYSIS
}

\author{
Alexandros Sotirios Anifantis ${ }^{1}$, Artur Przywara ${ }^{2}$, Simone Pascuzzi ${ }^{1}$, Francesco Santoro ${ }^{1}$ \\ ${ }^{1}$ University of Bari Aldo Moro, Italy; ${ }^{2}$ University of Life Sciences in Lublin, Poland \\ alexandrossotirios.anifantis@uniba.it, artur.przywara@up.lublin.pl,simone.pascuzzi@uniba.it, \\ francesco.santoro@uniba.it
}

\begin{abstract}
Mushrooms represent typical high quality and high-price niche products. Especially in summer, the mushroom price is usually high due to the limited production. The only way to cultivated mushrooms, during the hot season, is to decrease the air temperatures and increase the humidity content through use of cooling technologies in controlled environment. Unfortunately, the traditional systems used for greenhouse conditioning and the cooling cost are not economically sustainable in summer and the thermal levels reached inside the greenhouse are too low. Alternative solutions are represented by renewable energy plants as photovoltaic and geothermal integrated systems for greenhouse daytime cooling. In this paper, a small capacity heat pump (6.5 $\mathrm{kW}$ ) for cooling a greenhouse in south of Italy is analysed. The heat pump is coupled to a vertical closed loop geothermic borehole and the electric energy necessary to feed the heat pump is supplied by photovoltaic array. The average energy efficiency ratio of the heat pump, the operating parameters of the heating systems and the weather conditions outside and inside the greenhouse are investigated. The data collection and mushroom cultivation period was from 08 to 25 July 2016, but the results were reported from 21 to 25 July 2016. The analysis shows that the greenhouse environmental conditions reached in the greenhouse are sustainable for mushroom cultivation only when the heat pump is used. Thanks to the geothermic borehole the average energy efficiency ratio of the hat pump in cooling mode ranges from 6 to 8 , this value is double than the efficiency achieved by the traditional air to air source heat pumps. The results underline that the geothermal heat pump with high energy efficiency ratio improves the environmental conditions inside the greenhouse and represents a sustainable solution during the summer for high-price crops.
\end{abstract}

Keywords: geothermal; cooling; greenhouse; heat pump, mushrooms.

\section{Introduction}

During the summer season the profitability of a greenhouse can be quite low due to the high air temperatures inside the greenhouse and the cooling energy necessary to reach sustainable growing temperatures. To shorten the environmental control system investment recovery period, yield and high quality crops can be adopted [1]. Mushrooms represent a high income and fast growing crop. Pleurotus eryngii is a popular mushroom due to its excellent consistency of cap and stem, culinary qualities and longer shelf life. In Italy, where Pleurotus mushrooms are very popular, Pleurotus eryngii may take position among the consumers, but currently this mushroom is not cultivated on large scale. Unfortunately, in summer the environmental conditions do not allow mushroom cultivation in the south of Italy. The main limitations are high temperatures and low humidity that inhibit mushroom growth. Shading, fog systems and ventilation are commonly used due to their simplicity and low cost [2], but a hard cooling system is needed to overcome these problems. However, the cooling effects of the cited method are not sufficient to reach the ideal growth temperatures [3; 4]. A suitable solution can be represented by the use of shade greenhouses cooled by heat pumps with a high coefficient of performance [5].

In order to reduce the conditioning system's cost, the same heat pump can be used for heating and cooling the greenhouses on winter days and summer nights [6; 7]. However, in summer, the cooling of the greenhouse through heat pumps is possible only when the solar radiation entering the greenhouse is very low, since a large portion of it increases the cooling load [8;9]. This is the case of mushroom crops, where the levels of brightness and solar radiation must be kept extremely low.

The aims of this paper are to investigate: 1) the humidity and temperature inside a mushroom greenhouse cooled by geothermal heat pumps; 2) the average energy efficiency ratio (EER) of the heat pumps; and 3) the total weight of harvested fresh mushrooms per bale/total number of mushrooms harvested per bale. This study shows the prospects of Pleurotus eryngii cultivation in Italy and suggests further study in controlled environment for higher yield and production. 


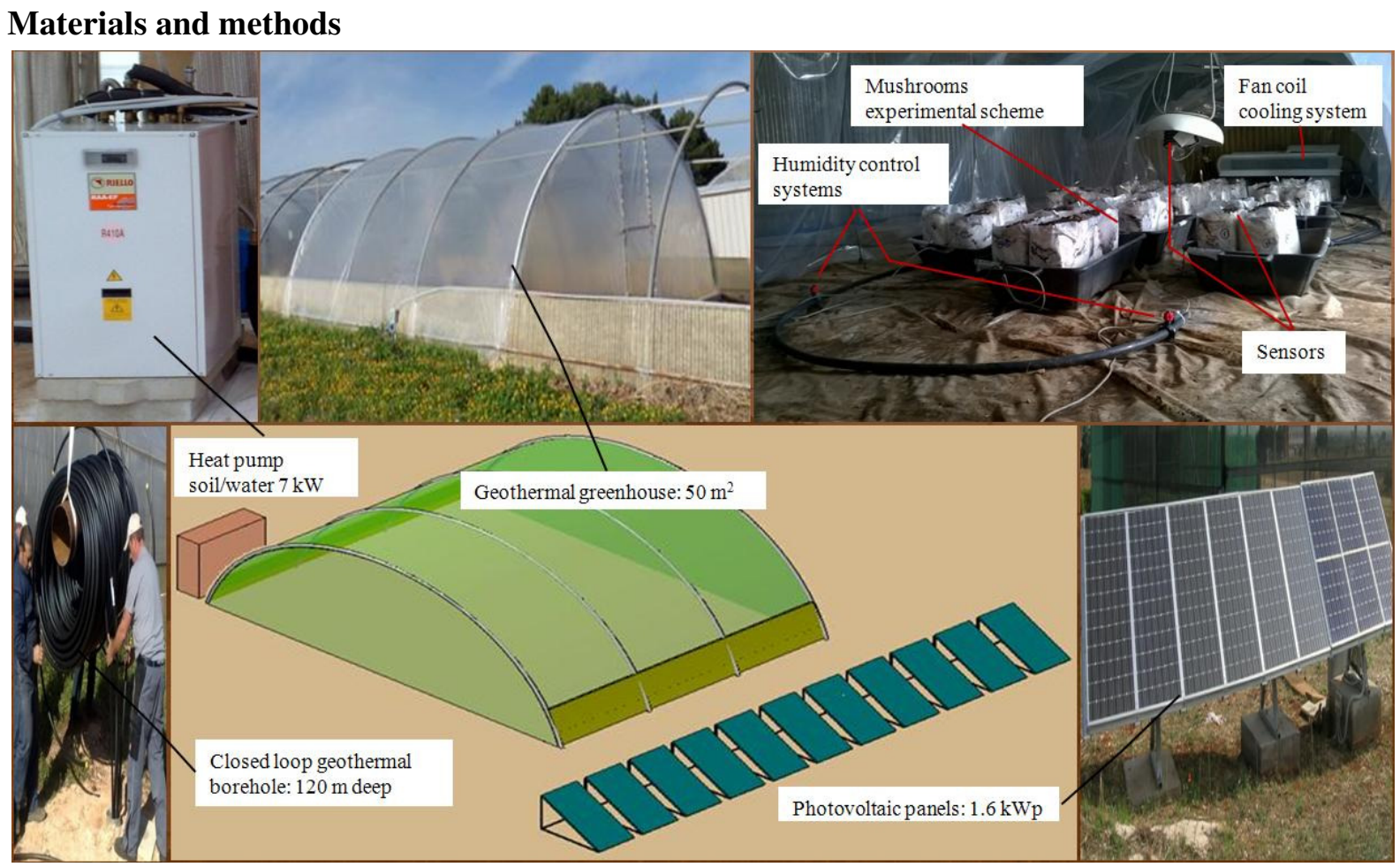

Fig. 1. Photovoltaic and low enthalpy geothermal systems for greenhouse cooling

This experiment was carried out from 08 to 25 July 2016. A single tunnel greenhouse (east-west orientation) located in Valenzano, Italy $\left(41^{\circ} 01^{\prime} 11.7^{\prime \prime} \mathrm{N} 16^{\circ} 54^{\prime} 15.8^{\prime \prime} \mathrm{E}\right)$ was used for this study. The greenhouse was $6 \mathrm{~m}$ long, $8 \mathrm{~m}$ large and $3.8 \mathrm{~m}$ high, with a total volume of $144 \mathrm{~m}^{3}$. Two layers of plastic films covered the greenhouse in order to improve the thermal isolation and to reduce significantly the light on mushroom crops (500-1.000 LUX). For the layer below an air inflated, double layer polyethylene film with a thickness of $180 \mu \mathrm{m}$ for avoiding the thermal losses was used. For the above layer a black/white polyethylene film with a thickness of $360 \mu \mathrm{m}$ was installed. One side is white to reflect the light and heat, while the other side is black to provide $100 \%$ light blockage. For this reason, the greenhouse cooling energy load can be determined neglecting the solar radiation contribution. A very small leak was allowed to daylight penetration. The inside ground area was covered with polyethylene film to limit the soil influence to the air temperature and humidity and also for preserved cultivation [10].

Two fan-coil units, each with the cooling/heating capacity of $2.28 / 3.59 \mathrm{~kW}$ and maximum air flow rate of $495 \mathrm{~m}^{3} \cdot \mathrm{h}^{-1}$ (Carisma CRC53MV) connected to a ground source heat pump with the cooling capacity of 5.5-7 kW (Model RAA-EF, Riello) were installed to keep an air temperature of 18 ${ }^{\circ} \mathrm{C}$ inside the greenhouse (Fig. 1). During the experiment, the greenhouse was fully closed. The hot side of the heat pump was connected to $120 \mathrm{~m}$ vertical double U-bend ground heat exchangers (thermal probe). The heating pumping unit uses R410A as refrigerant fluid circulating inside its circuit and the water flow rates in the hot and cold are 0.27 and $0.24 \mathrm{~kg} \cdot \mathrm{s}^{-1}$, respectively. The ground heat exchanger was designed in order to keep the sustainable energy production without alteration of the thermal characteristics of the subsoil in the long term [11-13]. The borehole for the probe was built in two steps. In the first step a $3 \mathrm{~m}$ vertical $180 \mathrm{~mm}$ nominal diameter hole was drilled and a PVC (Polyvinyl chloride), with $160 \mathrm{~mm}$ nominal diameter and $3.2 \mathrm{~mm}$ thickness, pipe was inserted. In the second step a $120 \mathrm{~m}$ vertical $140 \mathrm{~mm}$ nominal diameter hole was drilled. During the drilling time the ground composition and stratigraphy were investigated to evaluate the thermal characteristic of the subsoil, limestone and large clay layers and crevices composing mainly the ground. The thermal probe in the ground has been sized in accordance with the thermal conductivities and the thermal resistances, corresponding to the soil composition and reported in the German standard [14-16].

The double U-bend disposition has the following characteristics: continuity of operations in case of one pipe occlusion; lower thermal resistance than single $U$ bend type, lower nominal diameter of 
the pipe and consequent high speed of the fluid inside, high boundary area extend, high possibility of thermal short circuit $[17 ; 18]$. The borehole grouting was placed through injection on pressure of concrete from the bottom by means of a polyethylene pipe placed between the PEX pipes. The undisturbed ground temperature is $16^{\circ} \mathrm{C}$, at undisturbed ground temperature the radius is $0.5 \mathrm{~m}$. The evaluation of the ground characteristics allowed calculating the borehole specific power extraction equal to $55 \mathrm{~W} \cdot \mathrm{m}^{-1}$ [19-21]. The heat transfer circulating fluid was water, because the altitude of the site (130 m.a.s.l.) and its climatic conditions did not produce fluid freezing risks. Moreover, the use of water without antifreeze fluids (propylene glycol, ethylene glycol, and so on) allows preventing any pollution of the surrounding environment or chemical incompatibility with the materials of the system in case of probe crashed. In this study, two strains of Pleurotus eryngii, 142 and 146, were cultivated on wheat straw (chopped into about $2 \mathrm{~cm}$ portions) and exhausted beet slivers in foam rubber filters and their yield parameters were investigated. Forty-four bales were used, twenty-two of the strain 142 and twenty-two of the strain 146. The bales, each of the dimensions of $15 \times 25 \times 30 \mathrm{~cm}$, were distributed in 11 low-edge plastic trays. Each tray contained four bales: two per strain. In the greenhouse, the strains were distributed according to the Italian cultivation standards. The cultivation test started on July 8, 2016. The bale substrate was covered with $1.5 \mathrm{~cm}$ of ground. At the end of cultivation, the average weight of the collected basidia was calculated for each strain. All the parameters measured and calculated were compared with those typical of the strains 142 and 146 cultivated in their "optimal" period and obtained from the interviews carried out.

The relative humidity and air temperature inside and outside the greenhouses were collected using Pt100 sensors. The data were collected through data loggers CR10X Campbell, set with a sampling time of $10 \mathrm{~s}$ and the data storage time lag of $15 \mathrm{~min}$. Other eleven measuring points, using Pt100 sensors, one for each tray, were placed at $0.5 \mathrm{~m}$ above the ground near to the trays. Furthermore, sensors of the same type measured the outlet and inlet temperatures of both the sides (hot and cold) of the heat pump. Finally, a digital multimeter measured electricity consumption of the heat pump. Average energy efficiency ratio was given by the following formula:

$$
E E R=\frac{Q_{2}}{L}=\frac{Q_{2}}{Q_{1}-Q_{2}},
$$

where EER - energy efficiency ratio;

$Q_{2}$ - greenhouse cooling load, W;

$Q_{1}$ - ground source borehole heating load, W;

$L$ - heat pump electricity consumption, $\mathrm{W}$.

In the present experiment, the greenhouse cooling load can also be obtained by analyzing the greenhouse energy balance neglecting the solar radiation contribution [22]:

$$
Q_{2}=q \cdot \rho \cdot\left(h_{s}-h_{d}\right)
$$

where $q$-air flow rate, $\mathrm{m}^{3} \mathrm{~s}^{-1}$;

$\rho$ - density of dry air, $\mathrm{kg} \mathrm{m}^{-3}$;

$h_{s}$ - enthalpy at the air suction port of the internal unit of the heat pump, $\mathrm{kJ} \cdot \mathrm{kg}^{-1}$;

$h_{d}-$ enthalpy at the air discharge port of the internal unit of the heat pump, $\mathrm{kJ} \cdot \mathrm{kg}^{-1}$.

\section{Results and discussion}

Solar radiation, temperature and relative humidity of the ambient air $\left(T_{a}, R H_{a}\right)$ and the internal air of the greenhouse $\left(T_{i}, R H_{i}\right)$ for four representative summer days are reported in Fig. 2. The results show four clear sky days with solar radiation peaks of $1000 \mathrm{~W} \cdot \mathrm{m}^{-2}$ in order to analyze the behavior of the climate conditions inside the greenhouse and the performance of the heat pump in condition of greater cooling energy consumption of the greenhouse. The average temperature of the internal air of the greenhouse was set equal to $18{ }^{\circ} \mathrm{C}$, while the external air temperature ranges from $20^{\circ} \mathrm{C}$ to $36{ }^{\circ} \mathrm{C}$. The differences between the internal and external greenhouse temperatures, in the hours when the solar radiation peak is maximum, range from $12{ }^{\circ} \mathrm{C}$ to $16^{\circ} \mathrm{C}$. The relative humidity of the external air ranges from $20 \%$ to $50 \%$, while the average value of the internal air is $90 \%$ and, only for the coldest 
hours, the value ranges from $85 \%$ to $95 \%$ with a peak of $100 \%$, that is optimum for the basidia growth.
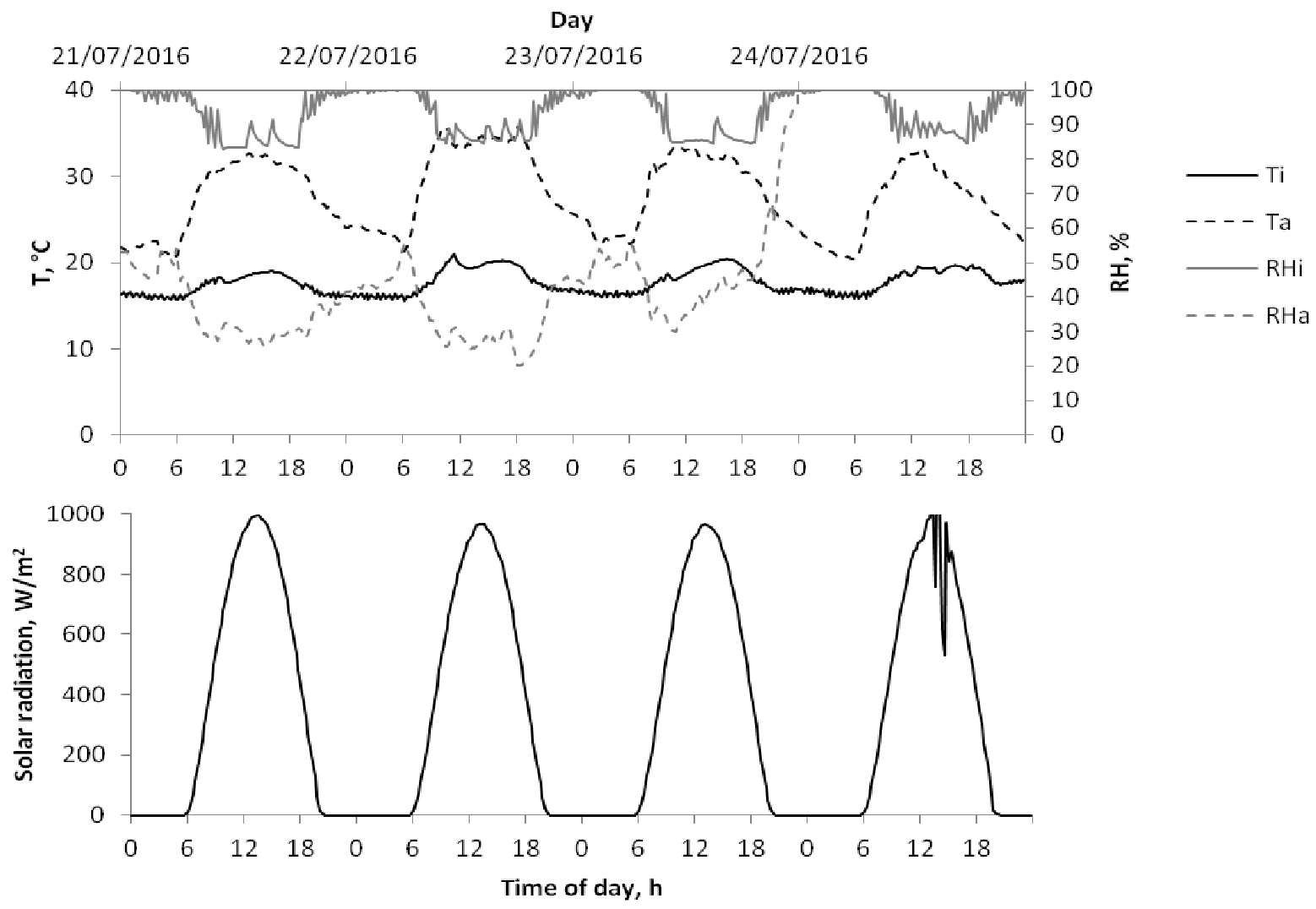

Fig. 2. Solar radiation, $T_{a}, R H_{a}, T_{i}$ and $R H_{i}$ during four representative summer days
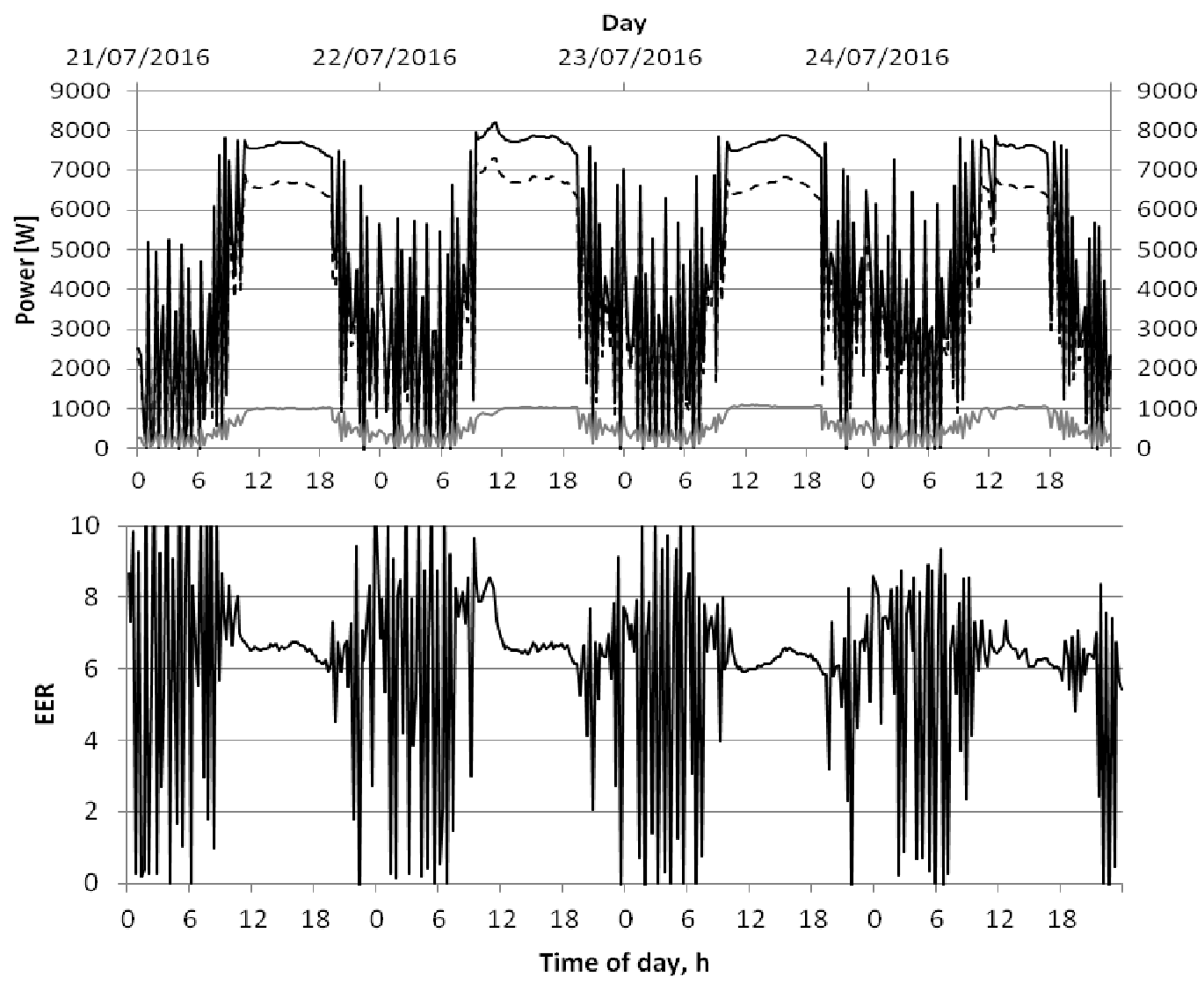

Fig. 3. $Q_{1}, Q_{2}, L$ and $E E R$ during four representative summer days 
The ground source borehole heating load $\left(Q_{1}\right)$, the greenhouse cooling load $\left(Q_{2}\right)$, the heat pump electricity consumption $(L)$ and the energy efficiency ratio (EER) for the four representative summer days are reported in Fig. 3. Considering $0.275 \mathrm{~m}^{3} \cdot \mathrm{s}^{-1}$ the air flow rate of the two fan-coil units $(q)$ and $1.225 \mathrm{~kg} \mathrm{~m}^{-3}$ the density of dry air $(\rho)$, the enthalpy at the air suction port $\left(T_{i s}=22^{\circ} \mathrm{C}, U R_{i s}=85 \%\right)$ of the inside split of the heat pump $\left(h_{s}\right)$ results equal to $58 \mathrm{~kJ} \cdot \mathrm{kg}^{-1}$, instead the enthalpy at the air discharge port $\left(T_{i d}=13.6{ }^{\circ} \mathrm{C}, U R_{i d}=100 \%\right)\left(h_{d}\right)$ results equal to $38 \mathrm{~kJ} \cdot \mathrm{kg}^{-1}$, then the greenhouse cooling load is $6.7 \mathrm{~kW}$ (Eq. 2). In summer period, the cooling system decreases the greenhouse temperature by 6 to $16^{\circ} \mathrm{C}$ depending on the hour of the day, the external air temperatures and the greenhouse cover material used. Taking in account the Eq. 1 and considering $7.7 \mathrm{~kW}$ the average ground source borehole heating load $\left(Q_{1}\right)$ and $1 \mathrm{~kW}$ the heat pump electricity consumption $(L)$, the EER of the heat pump ranges from 6.2 to 6.7. The EER value is quite high compared to the value reported by Tong et al. [22] due to the geothermal boreholes.
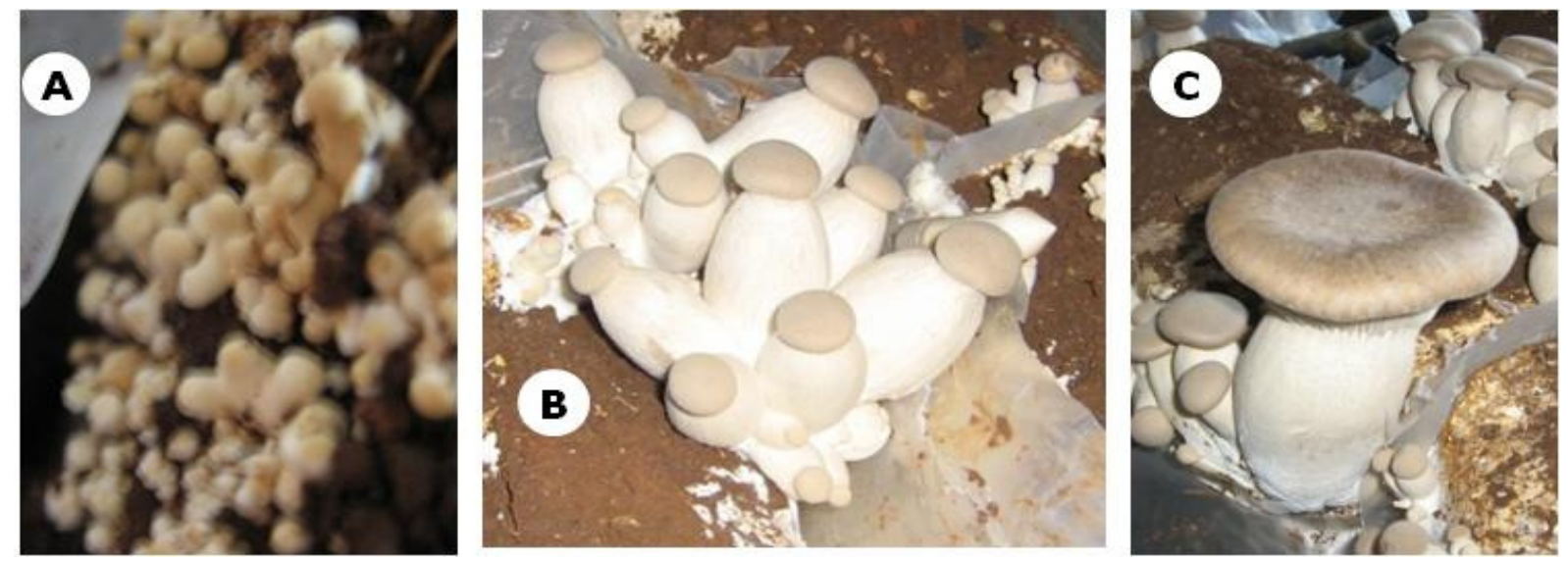

Fig. 4. Phases of cultivation of Pleurotus eryngii, strain 142: A - primordia; B - basidia after 11 days of planting; $\mathrm{C}$ - basidia ready to be harvested
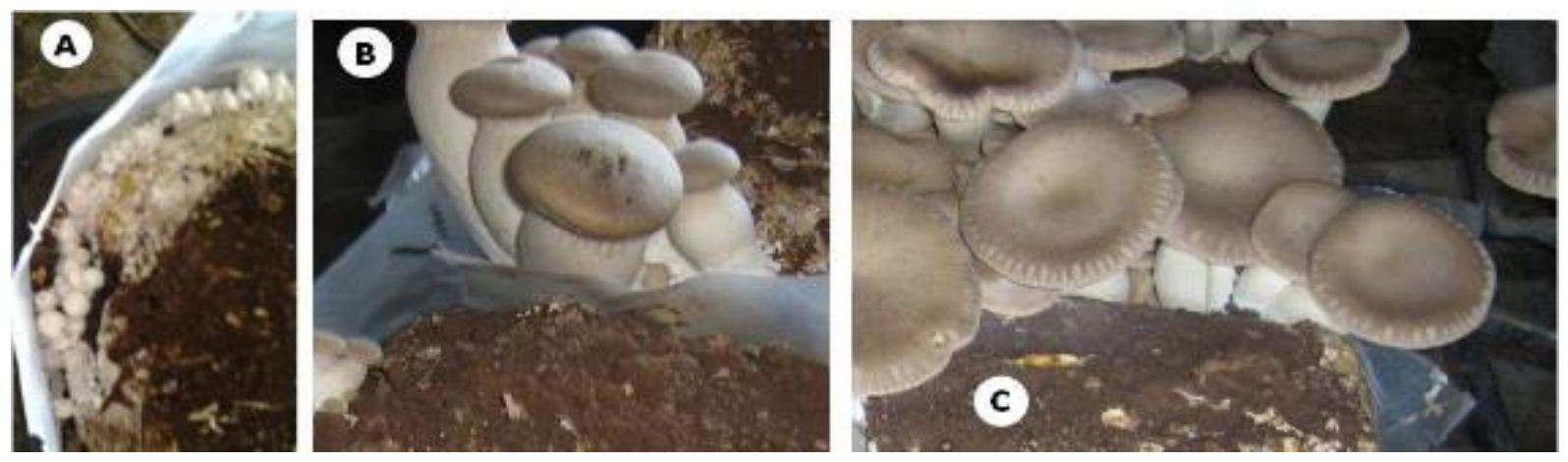

Fig. 5. Phases of cultivation of Pleurotus eryngii, strain 146: A - primordia; B - basidia after 11 days of planting; $\mathrm{C}$ - basidia ready to be harvested.

The appearance of the primordia occurred for the two strains, after 11 days from the opening of the loaves (Fig. 4 and Fig. 5). For both strains, the collection of the first harvesting was performed 18 days after planting.

The mean value and standard deviation of basidia yield were calculated and the mean values were also statistically separated through the Fisher's Least Significant Difference (LSD) with $P=0.05$. As shown in Table 1, the diameter of the cap of the strain 142 varies from 3 to $21 \mathrm{~cm}$, while the stipe has an average diameter of $2.3 \mathrm{~cm}$. Instead, the diameter of the cap of the strain 146 varies from 3 to $19 \mathrm{~cm}$, while the stipe has an average diameter of $2.9 \mathrm{~cm}$.

The comparison between the productions obtained in the air-conditioned greenhouse in summer and those of the two autumn-spring growing strains (obtained from the mushroom farm interviews) is shown in Fig. 6. No statistically significant difference was highlighted by the analysis performed among the productions (spring and summer) of the two strains. Not due to random events is, instead, 
the difference in production recorded between the strain 142 and 146 of P. eryngii, which sees the last one more productive.

Each bale of the 142 and 146 has produced about $500 \mathrm{~g}( \pm 15 \%)$ and $900 \mathrm{~g}( \pm 10 \%)$, respectively, in the first harvesting. The 146 showed higher biological yield (90\%) than the other strain (142). Also, the mycelium run rate and number of fruiting bodies were higher in 146 than the other strain. The quality of mushroom strains was near about similar. Mushroom pests and diseases were not observed during cultivation. Some types of stems are thickened, probably due to the high concentration of $\mathrm{CO}_{2}$ in the greenhouse environment.

Table 1

Dimensions and weight of mushroom basidia

\begin{tabular}{|c|c|c|}
\hline \multirow{2}{*}{ Parameter } & \multicolumn{2}{|c|}{ Strain * } \\
\cline { 2 - 3 } & $\mathbf{1 4 2}$ & $\mathbf{1 4 6}$ \\
\hline Number of basidia per bale & $32 \pm 7$ & $27 \pm 4$ \\
\hline Cap diameter, cm: & & 3 \\
min & 3 & $17.34 \pm 2.21$ \\
average** & $18.65 \pm 2.13$ & 19.0 \\
max & 21.0 & 2 \\
\hline $\begin{array}{c}\text { Stipe diameter, cm: } \\
\text { min }\end{array}$ & 2 & $2.9 \pm 0.75$ \\
average** & $2.3 \pm 0.82$ & 3.5 \\
max & 3 & \\
Basidia weight, g: & & $815.37 \pm 163.9$ \\
Bale average & $459.55 \pm 126.0$ & 17.935 \\
tot & 10.101 & \\
\hline
\end{tabular}

* average of 22 bales \pm standard deviation.

** average of 50 basidia \pm standard deviation.

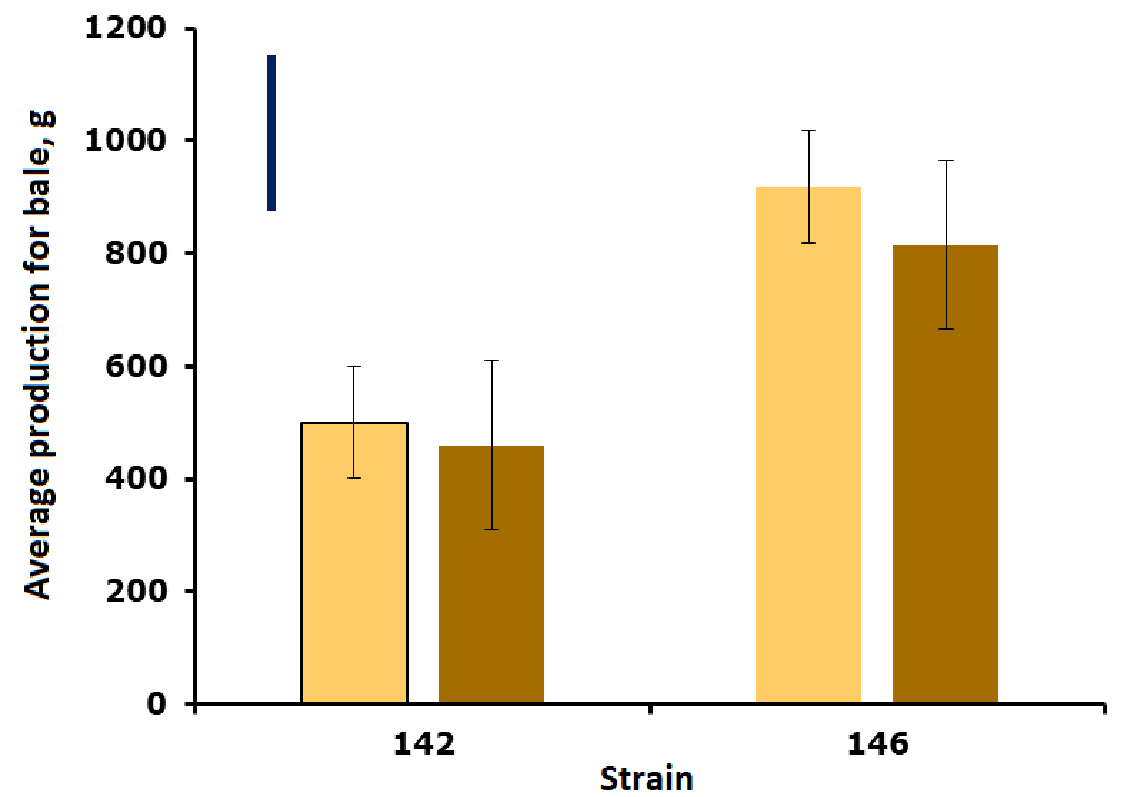

Fig. 6. Average production for bale: $\square$ - in summer period;

- in autumn/spring period; - LSD per $P=0.05$.

\section{Conclusions}

In the present paper, a small capacity heat pump was implemented for low temperature of a mushroom greenhouse in summer. The results show that the environmental conditions reached in the greenhouse are sustainable for mushroom cultivation only when the heat pump is used. Thanks to the geothermic borehole the average energy efficiency ratio of the heat pump in cooling mode ranges from 
6 to 8 , this value is about double than the efficiency achieved by the traditional air to air source heat pumps. The results underline that a geothermal heat pump with high energy efficiency ratio improves the environmental conditions inside the greenhouse and represents an economical sustainable solution only for shady and high income growing crops as mushrooms.

\section{Acknowledgements}

Funding source: Fondo di Sviluppo e Coesione 2007-2013 - APQ Ricerca Regione Puglia "Programma regionale a sostegno della specializzazione intelligente e della sostenibilità sociale ed ambientale- FutureInResearch". We gratefully acknowledge MICROTERMA and PATI for free supplying the equipment and supporting the research.

\section{References}

[1] Pascuzzi S., Blanco I., Anifantis A. S., Scarascia Mugnozza G. Hazards assessment and technical actions due to the production of pressured hydrogen within a pilot photovoltaic-electrolyser-fuel cell power system for agricultural equipment. J. Agric. Eng., vol. 47, 2016, pp. 88-93.

[2] Hassanien, R.H.E.; Li, M.; Dong Lin, W. Advanced applications of solar energy in agricultural greenhouses. Renew. Sustain. Energy Rev., vol. 54, 2016, pp. 989-1001.

[3] Anifantis A. S. Performance assessment of photovoltaic, ground source heat pump and hydrogen heat generator in a stand-alone systems for greenhouse heating. Chemical Engineering Transactions, vol. 58, 2017, pp. 511-516.

[4] Pascuzzi S., Anifantis A. S., Blanco I., Scarascia Mugnozza G. Electrolyzer performance analysis of an integrated hydrogen power system for greenhouse heating a case study. Sustainability (Switzerland), vol. 8(7), 2016, pp. 1-15.

[5] Fujii H., Ohyama K. Application of ground source heat pumps for air conditioning of greenhouses. IEA Heat Pump Centre Newsletter, vol. 27, 2009, pp. 39-42.

[6] Lund J. W., Freeston D. H., Boyd T. L. Direct application of geothermal energy: 2005 worldwide review. Geothermics, vol. 34, 2005, pp. 691-727.

[7] Anifantis A. S., Colantoni A., Pascuzzi S., Santoro F. Photovoltaic and hydrogen plant integrated with a gas heat pump for greenhouse heating: A mathematical study. Sustainability (Switzerland), vol. 10(2), 2018, pp. 1-12.

[8] Blanco I.; Anifantis A.S.; Pascuzzi S.; Scarascia Mugnozza G. Hydrogen and renewable energy sources integrated system for greenhouse heating. J. Agric. Eng., vol. 44, 2013, pp. 226-230.

[9] Chai L., Ma C., Ni J.-Q. Performance evaluation of ground source heat pump system for greenhouse heating in northern China. Biosystems Enginnering, vol. 111(1), 2012, pp. 107-117.

[10]Russo G., Verdiani G., Anifantis A.S. Re-use of agricultural biomass for nurseries using proximity composting. Contemp. Eng. Sci., vol. 9, 2016, pp. 1151-1182.

[11] Adaro J. A., Galimberti P. D., Lema A. I., Fasulo A., Barral J. R. Geothermal contribution to greenhouse heating. Applied Energy, vol. 64(1-4) , 1999, pp. 241-249.

[12] Anifantis A. S., Colantoni A., Pascuzzi S. Thermal energy assessment of a small scale photovoltaic, hydrogen and geothermal stand-alone system for greenhouse heating. Renewable Energy, vol. 103, 2017, pp. 115-127.

[13] Benli H. A performance comparison between a horizontal source and a vertical source heat pump systems for a greenhouse heating in the mild climate Elaziğ, Turkey. Applied Thermal Engineering, vol. 50(1), 2013, pp. 197-206.

[14] Florides G. A., Pouloupatis P. D., Kalogirou S., Messaritis V., Panayides I., Zomeni Z., Partasides G., Lizides A., Sophocleous E., Koutsoumpas K. The geothermal characteristics of the ground and the potential of using ground coupled heat pumps in Cyprus. Energy, vol. 36(8), 2011, pp. 5027-5036.

[15] VDI 4640 Blatt 2 standard "Thermische Nutzung Des Untergrundes - Erdgekoppelte Wärmepumpenanlagen”, 2009.

[16] VDI 4640 Blatt 4 standard "Thermische Nutzung Des Untergrundes - Direkte Nutzungen", 2004.

[17] Anifantis A. S., Pascuzzi S., Scarascia Mugnozza G. Geothermal source heat pump performance for a greenhouse heating system: An experimental study. J. Agric. Eng., vol. 47, 2016, pp. 164-170. 
[18] Ozgener O. Use of solar assisted geothermal heat pump and small wind turbine systems for heating agricultural and residential buildings. Energy, vol. 35(1), 2009, pp. 262-268.

[19] Benli H., Durmuş A. Evaluation of ground-source heat pump combined latent heat storage system performance in greenhouse heating. Energy and Building, vol. 41(2), 2009, pp. 220-228.

[20] Ozgener O., Hepbasli A. Performance analysis of a solar-assisted ground-source heat pump system for greenhouse heating: An experimental study. Build. Environ., vol. 40, 2005, pp. 1040-1050.

[21] Sharqawy M. H., Mokheimer E. M., Badr H. M. Effective pipe-to-borehole thermal resistance for vertical ground heat exchangers. Geothermics, vol. 38(2), 2009, pp. 271-277.

[22] Tong Y., Kozai T., Ohyama K. Performance of household heat pumps for nighttime cooling of a tomato greenhouse during the summer. Applied engineering in agricultural, vol. 29(3), 2013, pp. 414-421. 